\title{
Heavy Metals Contents and Health Risk Assessment of Classroom Corner Dusts in Selected Public Primary Schools in Rivers State, Nigeria
}

\author{
Olua Victor*, Patrick-Iwuanyanwu Kingsley Chukwuemeka, Nwaichi Eucharia Oluchi \\ Department of Biochemistry, Faculty of Science, University of Port Harcourt \\ *Corresponding author: vyckol@yahoo.com
}

Received April 05, 2018; Revised September 11, 2018; Accepted September 28, 2018

\begin{abstract}
Heavy metals are shown to be a major indoor dusts pollutant. The health risk assessment of Heavy metal contents of dusts collected from classroom corners of some randomly selected public primary schools in Rivers state was carried out. Dust samples from Classroom corners of three (3) Public primary Schools in Obio/Akpor, Eleme, and Ikwerre Local Government Areas (LGAs) was collected and analyzed for Lead (Pb), Cadmium (Cd), Chromium (Cr), and Arsernic (As) using Atomic Absorption Spectrophotometer (AAS, GF, Flame HVG). The heavy metal concentrations obtained from the analysis revealed that mean maximum level for $\mathrm{Pb}$ and $\mathrm{Cd}$ were obtained from $\mathrm{E}$ at $25.39 \pm 0.09$ and $3.52 \pm 0.23 \mathrm{mg} \mathrm{kg}^{-1}$ respectively, while that of $\mathrm{Cr}$ and As were obtained from $\mathrm{H}$ at $45.24 \pm 0.02$ and $1.53 \pm 0.06 \mathrm{mg} \mathrm{kg}^{-1}$. The minimum levels were observed at $\mathrm{E}$. The Average daily intake Dose $\left(\mathrm{ADD}_{\text {ingestion, dermal }}\right.$ and inhalation) and corresponding Target Hazard Quotients obtained revealed oral ingestion as major exposure pathway, though with no evidence for non carcinogenic risk/Hazard index (HI), but with children population being more exposed to Life cancer Risks (TLCR) except at F. It is however recommended that same risk assessment be made on agricultural products harvested from Primary School Farms and Borehole water within these regions.
\end{abstract}

Keywords: heavy metals, dusts, public primary school, carcinogenic risks

Cite This Article: Olua Victor, Patrick-Iwuanyanwu Kingsley Chukwuemeka, and Nwaichi Eucharia Oluchi, "Heavy Metals Contents and Health Risk Assessment of Classroom Corner Dusts in Selected Public Primary Schools in Rivers State, Nigeria." Journal of Environment Pollution and Human Health, vol. 6, no. 4 (2018): 138-147. doi: 10.12691/jephh-6-4-3.

\section{Introduction}

The indiscriminate, frequent, deliberate and accidental release of hazardous, harmful substances has become a major source of environmental pollution. This has led to major problem experienced in developing countries as it has to do with improper management of wastes within our environment, which has gone a long way towards contributing to environmental contamination and pollution, hence making our environment potentially hazardous/risky.

Indoor dust over time has drawn the attention of researchers as people spend up to $90 \%$ of their time in indoor environments such as homes, schools and offices [1,2,3] thereby coming in contact with surfaces contaminated with such dusts .

Indoor dust could be defined as fine settled airborne particles less than $100 \mu \mathrm{m}$ in indoor environments. Pollutants in indoor dust may be derived from exterior and interior sources which could be anthropogenic in nature. Several studies have shown that indoor dust could act as a carrier of inorganic and organic pollutants such as heavy metals, polycyclic aromatic hydrocarbons, pesticides and polychlorobiphenyls [3-11].
Studies have shown that Children are vulnerable to contaminated indoor dusts, as this could be attributed to their behavioural pattern seen in their hand-to-mouth life style, crawling, fast growth rate and playing with toys and teddies $[5,12,13]$. It is note worthy that of all the predominant routes to heavy metal contamination, studies have shown that ingestion of dust by children is the main heavy metal exposure pathway as children are predisposed to playing on the floor and ingest the dusts indirectly and unknowingly [14].

\section{Materials and Methods}

\subsection{Reagents}

Hydrogen tetraoxosulphate (vi) acid $\left(\mathrm{H}_{2} \mathrm{SO}_{4}\right)$, Trioxonitrate (v) acid $\left(\mathrm{HNO}_{3}\right)$, Perchloric acid $\left(\mathrm{HClO}_{4}\right)$, Air, Acetylene.

\subsection{Materials/Equipments}

Sampled dusts, Hollow cathode lamps, Graphical display and recorder, Solar thermo elemental Atomic Absorption Spectrophotometer (Flame AAS) model: S4=71096. 


\subsection{Study Area}

The study area covers public primary schools within the urban, Industrialized and rural area in Rivers State Nigeria. Primary schools at Obio/Akpor, Eleme and Ikwerre Local Government areas represents good sample sites respectively and hence were chosen. Sample A, B and C represents dusts from classroom corners of Public Primary School in Obio/Akpor Local Government Area (Urban Region). Sample D, E and F represents dusts from classroom corners of Public Primary School in Eleme Local Government Area (Industrialized Region), while Sample G, H and I represents dusts from classroom corners of Public Primary School in Ikwerre Local Government Area (Rural Region).

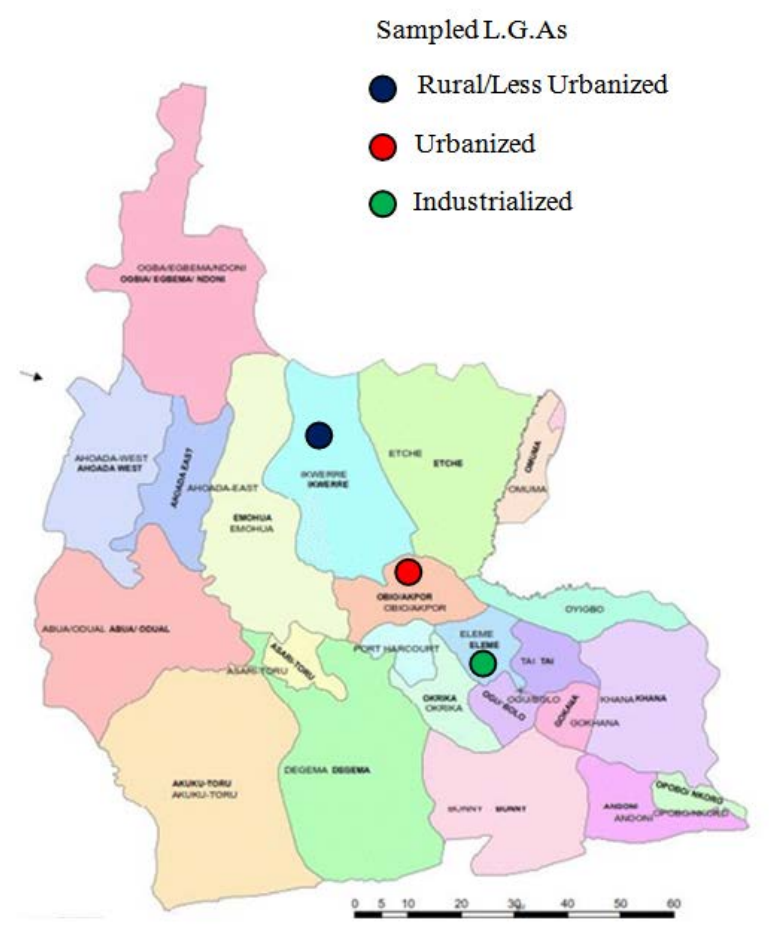

Figure 1. Map of Rivers State showing sampled sites

\subsection{Sample Collection and Preparation}

Dust samples were collected from the study sites using hard brush and foil, at each sampling point about $50 \mathrm{~g}$ of dust samples were collected from classroom corners. The collected samples were put into sterile bottles and labeled appropriately before taking them to the laboratory for digestion and analysis.

Each sample was analysed for heavy metals $\mathrm{Pb}, \mathrm{As}, \mathrm{Cd}$, Cr, using Atomic Absorption Spectrophotometry.

\subsection{Wet digestion Method}

A total volume of $100 \mathrm{ml}$ of $\mathrm{H}_{2} \mathrm{SO}_{4}, \mathrm{HNO}_{3}$, and $\mathrm{HClO}$ in the rato of $40 \%: 40 \%: 20 \%$ was mixed together, $1 \mathrm{~g}$ of the sample was weighed into a conical flask, $2 \mathrm{ml}$ of the mixed acid was added to each of the sample in the conical flask, and was digested in a fume cupboard with hot plate until white fumes appear. The solution was cooled and filtered into a $100 \mathrm{ml}$ volumetric flask and made upto mark with distilled water.

\subsection{Atomic Adsorption Spectrophotometer (AAS) PROCEDURE}

Heavy metals (Lead, Cadmium, Chromium, and Arsenic) were analyzedusing AAS Model:S4=71096, with eight-socket hollow cathode lamps. The gases used in this instrument were acetylene and air.

The hallow cathode lamp of desired metal was installed and the wavelength dial set. The equipment was left to warm up for about 10-20 minutes for energy source to stabilize and the current was readjusted. Suitable burner head was installed, and the position adjusted. Air was turned on and its flow rate adjusted to give maximum sensitivity for the metal being measured The required metal to be determined in the machine was chosen and blank aspirated inside the machine to zero the instrument. The standard solution (2ppm) of the choice metal was aspirated. The aspiration rate of the nebulizer was adjusted to obtain maximum sensitivity. The machine was finally calibrated by aspirating with $0.5 \mathrm{ppm}$ of metal. Samples were then aspirated into the flame and atomized. The samples were analyzed by the machine and their absorbance's were recorded with the report automatically displayed and printed by clicking print report from the report menu.

\subsection{Health Risk Assessment}

Health risk assessment can be defined as risk characterization of the potential adverse health effects of human exposure to contaminants [15]. The IARC has classified the carcinogens into five categories to indicate whether the agents can cause cancer, which include Group 1 (carcinogenic to humans), Group 2A (probably carcinogenic to humans), Group 2B (possibly carcinogenic to humans), Group 3 (not classifiable as carcinogenic to humans) and Group 4 (probably not carcinogenic to humans). From the IARC agents' classification, As, Cd, $\mathrm{Cr}$ and $\mathrm{Pb}$ are classified as potential non-carcinogenic and carcinogenic elements, whereas other heavy metals ( $\mathrm{Al}$, $\mathrm{Co}, \mathrm{Cu}, \mathrm{Fe}, \mathrm{Ni}$ and $\mathrm{Zn}$ ) are treated as non-carcinogenic elements. According to the Exposure Factors Handbook [16] the average daily dose (ADD) $\left(\mathrm{mgkg}^{-1} \mathrm{day}^{-1}\right)$ (Chronic daily intake, CDI) of heavy metals via ingestion, dermal contact and inhalation was estimated using the following equations, respectively:

$$
\begin{aligned}
& \mathrm{ADD}_{\text {ingest }}=\mathrm{C} \times \mathrm{IngR} \times \mathrm{EF} \times \mathrm{ED} \times \mathrm{CF} / \mathrm{BW} \times \mathrm{AT} \\
& \mathrm{ADD}_{\text {dermal }}=\mathrm{C} \times \mathrm{SA} \times \mathrm{AF} \times \mathrm{FE} \times \mathrm{ABS} \times \mathrm{EF} \times \mathrm{ED} \times \mathrm{CF} / \mathrm{BW} \times \mathrm{AT}, \\
& \mathrm{ADD}_{\text {inhale }}=\mathrm{C} \times \mathrm{InhR} \times \mathrm{EF} \times \mathrm{ED} / \mathrm{PEF} \times \mathrm{BW} \times \mathrm{AT},
\end{aligned}
$$

where $\mathrm{C}$ is the concentration of heavy metals $(\mathrm{mg} / \mathrm{kg})$; IngR $=$ the ingestion rate $\left(\right.$ mgday $\left.^{-1}\right) ; \mathrm{SA}=$ the surface area of the skin exposed to heavy metal $\left(\mathrm{cm}^{2}\right)$; AF = the skin adherence factor $\left(\mathrm{mg} / \mathrm{cm}^{2} \mathrm{day}^{-1}\right) ; \mathrm{ABS}=$ the dermal absorption factor $\left(\mathrm{mg} / \mathrm{cm}^{2}\right) ; \mathrm{InhR}=$ the inhalation rate $\left(\mathrm{m}^{3}\right.$ day $\left.{ }^{-1}\right) ; \mathrm{PEF}$, the particle emission factor $\left(\mathrm{m}^{3} / \mathrm{kg}\right)$; EF, the exposure frequency (days/year); ED=the exposure duration (year); $\mathrm{BW}=$ the body weight $(\mathrm{kg}) ; \mathrm{AT}=$ the averaging time (days); $\mathrm{FE}=\mathrm{Dermal}$ exposure ratio and $\mathrm{CF}=$ the conversion factor.

The parameters of the ADD, reference dose (RfD) and cancer slope factor (CSF), which were obtained from the Exposure Factors Handbook [16], Integrated Risk Information System $[17,18]$ are shown in Table 1 to 
Table 3. Additionally, the risks can be classified as non-carcinogenic risks and carcinogenic risks. Both non-carcinogenic and carcinogenic risk exposure for children and adult were calculated using Hazard Quotient (HQ) and Life Cancer Risk (LCR), respectively.

For non-carcinogenic risk, the HQ for children and adult during a lifetime can be calculated by dividing the ADD from each exposure pathway by a specific RfD as shown, whereas ADD is the average daily dose and RfD is the estimated maximum permissible risk posed to humans through daily exposure. Subsequently, the calculated HQ for all three exposure pathways (ingestion, dermal contact and inhalation) was summed to obtain the Hazard Index (HI). In the event of $\mathrm{HI} \leq 1$, then adverse health effects would be unlikely to occur. However, potential non-carcinogenic effects would occur when $\mathrm{HI}>1$ as this indicates that there is significant non-carcinogenic risk that is posed to human health.

The formula used for calculation of HQ

$$
H Q=\frac{\left(M_{c} \times \mathrm{IR} \times 10^{-3} \times \mathrm{EF} \times \mathrm{ED}\right)}{(R f D \times B W \times A T n)}
$$

Or

$$
\begin{gathered}
\mathrm{HQ}=\mathrm{ADD} / \mathrm{RfD}, \\
\mathrm{HI}=\mathrm{HQ}_{\text {ingest }}+\mathrm{HQ}_{\text {dermal }}+\mathrm{HQ}_{\text {inhale }}
\end{gathered}
$$

For carcinogenic risk, the LCR of children caused by potential carcinogen exposure over a lifetime can be calculated as shown below, for ADD and SF is the slope factor for cancer. Total Life Cancer Risk (TLCR) adds up all LCRs calculated for ingestion, dermal contact and inhalation. The acceptable range of TLCR for carcinogenic risk is in the range of $1 \times 10^{-6}-1 \times 10^{-4}$. If the risk exceeds the range, this implies that carcinogenic risks exist and the potential carcinogenic effect would likely occur.

$$
\begin{gathered}
\mathrm{LCR}=\mathrm{ADD} \times \mathrm{SF}, \\
\mathrm{TLCR}=\mathrm{LCR}_{\text {ingest }}+\mathrm{LCR} \text { dermal }+\mathrm{LCR}_{\text {inhale. }}
\end{gathered}
$$

\subsection{Statistical Analysis}

The analysis of variance was done using SPSS version 20.

\begin{tabular}{|c|c|c|c|}
\hline \multirow{2}{*}{ Parameter } & \multirow{2}{*}{ Symbol } & \multicolumn{2}{|c|}{ Value } \\
\hline & & ADULT & CHILD \\
\hline Ingestion rate & IngR & $100 \mathrm{mg}$ & $200 \mathrm{mg}$ \\
\hline Exposure duration & $\mathrm{ED}$ & 24 years & 6 years \\
\hline Exposure frequency & $\mathrm{EF}$ & 350 days & 350 days \\
\hline Average body weight & BW & 70 & $15 \mathrm{~kg}$ \\
\hline \multirow{2}{*}{ Averaging time (AT) } & ATnon-carcinogenic & $\mathrm{ED} \times 365$ days & $\mathrm{ED} \times 365$ days \\
\hline & ATcarcinogenic & $70 \times 365$ days & $70 \times 365$ days \\
\hline Conversion factor & $\mathrm{CF}$ & $1 \times 10^{-6} \mathrm{~kg} / \mathrm{mg}$ & $1 \times 10^{-6} \mathrm{~kg} / \mathrm{mg}$ \\
\hline Surface area of skin & SA children & $5800 \mathrm{~cm}^{2}$ & $2800 \mathrm{~cm}^{2}$ \\
\hline Skin adherence factor & AFdust & $0.07 \mathrm{mg} / \mathrm{cm}^{2} /$ day & $0.2 \mathrm{mg} / \mathrm{cm} 2 /$ day \\
\hline \multirow{2}{*}{ Dermal absorption factor } & ABS non-carcinogenic & $0.001 \mathrm{mg} / \mathrm{cm}^{2}$ & $0.001 \mathrm{mg} / \mathrm{cm}^{2}$ \\
\hline & ABS carcinogenic & $0.03 \mathrm{mg} / \mathrm{cm}^{2}$ & $0.03 \mathrm{mg} / \mathrm{cm}^{2}$ \\
\hline Inhalation rate & InhR & 20 & $10 \mathrm{~m}^{3} /$ day \\
\hline Particle emission factor & PEF & $1.36 \times 10^{9} \mathrm{~m}^{3} / \mathrm{kg}$ & $1.36 \times 10^{9} \mathrm{~m}^{3} / \mathrm{kg}$ \\
\hline Dermal exposure ratio & $\mathrm{FE}$ & 0.61 & 0.61 \\
\hline
\end{tabular}

Table 1. Recommended standard values for dusts Health Risk Assessment

\begin{tabular}{cccc}
\hline Parameters & Pb (mg/kg) & Cd(mg/kg) & Cr(mg/kg) \\
\hline RFDing & 0.0035 & 0.001 & 0.003 \\
RFDinh & $3.50 \mathrm{E}-02$ & 0.001 & 0.0001 \\
RFDdermal & $5.25 \mathrm{E}-04$ & 0.00001 & 0.00006 \\
CSFing & 0.0085 & 6.3 & 0.5 \\
CSFinh & $4.20 \mathrm{E}-02$ & 6.3 & $1.00 \mathrm{E}-03$ \\
CSFdermal & - & - & $1.00 \mathrm{E}-05$ \\
\hline
\end{tabular}

$[16,17,18,19,20]$

Table 2.

$[18,19,16,21]$

Table 3.

\begin{tabular}{llc}
\hline Parameter & Symbol & Value \\
\hline Reference dose of cadmium & $\mathrm{RfDCd}$ & $0.001 \mathrm{mg} / \mathrm{kg} / \mathrm{day}$ \\
Reference dose of arsenic & $\mathrm{RfDAs}$ & $0.0003 \mathrm{mg} / \mathrm{kg} / \mathrm{day}$ \\
Reference dose of lead & $\mathrm{RfDPb}$ & $0.0035 \mathrm{mg} / \mathrm{kg} / \mathrm{day}$ \\
Reference dose of chromium & $\mathrm{RfDCr}$ & $0.003 \mathrm{mg} / \mathrm{kg} / \mathrm{day}$ \\
Cancer slope factor of arsenic & $\mathrm{CSFAs}$ & $1.5 \mathrm{mg} / \mathrm{kg} / \mathrm{day}$ \\
Cancer slope factor of cadmium & $\mathrm{CSFCd}$ & $6.3 \mathrm{mg} / \mathrm{kg} / \mathrm{day}$ \\
Cancer slope factor of chromium & $\mathrm{CSFCr}$ & $0.5 \mathrm{mg} / \mathrm{kg} / \mathrm{day}$ \\
Averaging time for carcinogenic & ATcarcinogenic & $70 \times 365$ days \\
Cancer slope factor of lead & $\mathrm{CSFPb}$ & $0.0085 \mathrm{mg} / \mathrm{kg} / \mathrm{day}$ \\
\hline
\end{tabular}

$[17,18]$. 


\section{Results and Discussion}

\subsection{Heavy Metal Contents of Dust Samples from selected Public Primary Schools in Rivers State}

The mean levels of the heavy metal contents of dust samples from classroom corners of three selected public primary schools in three Local Government Areas (Obio/Akpor, Eleme and Ikwerre) are as shown in Table 4. The result of this study showed $\mathrm{Pb}$ mean levels ranged from $10.26 \pm 0.02$ to $25.39 \pm 0.06 \mathrm{mgKg}^{-1}$ with highest $\mathrm{Pb}$ level observed at $\mathrm{E}$ and minimum level at $\mathrm{F}$. It is notable that the presence of $\mathrm{Pb}$ in the dust samples corroborates the findings of [22] who stated the presence of $\mathrm{Pb}$ in the classroom dusts of schools within Lagos State. It has also been reported that $\mathrm{Pb}$ may become toxic to plants and animals if their concentrations exceed permissible limits in soil and plant [23], as $\mathrm{Pb}$ has the ability to inhibit water imbalance, alter mineral nutrition, enzyme activities, hormonal status and membrane permeability alteration. $\mathrm{Pb}$ at increased concentrations could inhibit cellular activities thus causing cell death [24]. It has a toxic and destructive effect on the central nervous system, kidneys, liver, reproductive system, the most severe effect being brain necrosis, these hence poses dangerous threat to exposed individuals $[25,26,27]$. The $\mathrm{Pb}$ Levels were also seen to be within close range to the level obtained by Addo et al., [28] (in Ketu south District Ghana) and Popoola et al., [22] (Lagos Nigeria). The low levels of $\mathrm{Pb}$ in this study could be attributed to the ban on leaded gasoline in Nigeria which often time is an important input to $\mathrm{Pb}$ pollution in urban environment as well as low productivity of most Industries in Rivers State. The result also revealed highest $\mathrm{Pb}$ Levels within the industrialized region (Eleme LGA). It has been reported that exposure to $\mathrm{Pb}$ can cause damage or reduce children's intelligence (IQ) and academic performance. It also has the potential to decrease hearing ability and sight of children, and cause memory loss and attention deficit and disorders [29].

Cadmium mean levels ranged between $0.18 \pm 0.01$ to $3.52 \pm 0.17 \mathrm{mgKg}^{-1}$ with highest Cd level observed within $\mathrm{E}$ and minimum level at F. Reports by Aydinalp and Marinova, shows that $\mathrm{Cd}$ does not have any known beneficial effects and could become toxic to plants and animals [23], whereas Asia et al., [26] stated that Cd is seen to be toxic even if absorption by ingestion is low. Chronic exposure to high levels of Cd in food causes bone disorders, including osteoporosis and osteomalacia [26]. EPA, [30], accounted for the moderately toxicity of Cd to all organisms, with cumulative poisoning in animals concentrating at the liver, kidney, pancreas and thyroid of humans and other mammals [30]. It's major route of entrance to the human body is through the gastrointestinal tract by consumption of food products grown on contaminated soil, however smokers may receive a considerable part of their Cd intake by inhaling cigarette smoke [31,32].

Chromium mean levels obtained ranged from 19.03 \pm 0.01 to $45.24 \pm 0.02 \mathrm{mgKg}^{-1}$. Maximum Cd value was obtained at $\mathrm{H}$ while $\mathrm{F}$ has minimum values.

Studies have shown that Occupational exposure to $\mathrm{Cr}(\mathrm{III})$ is associated with respiratory effects with an evidenced coughing, wheezing, and decreased forced volume after an inhalation exposure to a sample of Cr(III) sulfate [33]. Pulmonary defects or symptoms such as; asthma, chronic bronchitis, chronic irritation, chronic pharyngitis, chronic rhinitis, congestion and hyperemia, polyps of the upper respiratory tract, tracheobronchitis, and ulceration of the nasal mucosa with possible septal perforation may proceed with inhalation of chromium dust [34,35].

Dermal exposure to chromium has been shown to produce irritant and allergic contact dermatitis [36,37]. Chromium is absorbed into the skin and triggers an immune response (sensitization). Sensitized individuals will showcase an allergic dermatitis response when exposed to high chromium level [36]. Localized erythematous or vesicular lesions at points of contact or generalized eczematous dermatitis should suggest sensitization [38].

Occupational exposure to $\mathrm{Cr}(\mathrm{VI})$ compounds in a number of industries has been associated with increased risk of respiratory system cancers [39]. Recent studies also disclosed excessive risk of lung cancer death resulting from occupational exposure to Cr(VI) compounds, [40,41]. Carcinogenicity appears to be associated with the inhalation of the less soluble/insoluble $\mathrm{Cr}(\mathrm{VI})$ compounds. The toxicology of $\mathrm{Cr}(\mathrm{VI})$ does not reside with the elemental form. It varies greatly among a wide variety of very different $\mathrm{Cr}(\mathrm{VI})$ compounds [42].

Table 4. HEAVY METAL CONTENT OF DUSTS IN PUBLIC PRIMARY SCHOOLS

\begin{tabular}{|c|c|c|c|c|c|}
\hline \multicolumn{2}{|c|}{ SAMPLE SITE } & $\mathrm{Pb}$ (mg/kg) & Cd(mg/kg) & $\mathrm{Cr}(\mathrm{mg} / \mathrm{kg})$ & As(mg/kg) \\
\hline \multirow{3}{*}{ OBIO/AKPOR } & A & $14.61 \pm 0.17^{\mathrm{a}}$ & $1.35 \pm 0.01^{\mathrm{a}}$ & $40.28 \pm 0.12^{\mathrm{a}}$ & $0.50 \pm 0.23^{\mathrm{a}}$ \\
\hline & B & $21.30 \pm 0.01^{\mathrm{a}}$ & $1.57 \pm 0.01^{\mathrm{b}}$ & $36.60 \pm 0.23^{\mathrm{a}}$ & $1.16 \pm 0.06^{\mathrm{b}}$ \\
\hline & C & $18.14 \pm 0.03^{\mathrm{a}}$ & $1.28 \pm 0.01^{\mathrm{c}}$ & $30.74 \pm 0.00^{\mathrm{a}}$ & $1.02 \pm 0.01^{\mathrm{c}}$ \\
\hline \multirow{3}{*}{ ELEME } & D & $15.42 \pm 0.23^{\mathrm{a}}$ & $0.53 \pm 0.01^{\mathrm{a}}$ & $26.40 \pm 0.17^{\mathrm{a}}$ & $0.10 \pm 0.01^{\mathrm{a}}$ \\
\hline & $\mathbf{E}$ & $25.39 \pm 0.06^{\mathrm{a}}$ & $3.52 \pm 0.17^{\mathrm{a}}$ & $38.21 \pm 0.12^{\mathrm{a}}$ & $1.24 \pm 0.07^{\mathrm{d}}$ \\
\hline & $\mathbf{F}$ & $10.26 \pm 0.02^{\mathrm{a}}$ & $0.18 \pm 0.01^{\mathrm{a}}$ & $19.03 \pm 0.01^{\mathrm{a}}$ & $0.058 \pm 0.01^{\mathrm{a}}$ \\
\hline \multirow{3}{*}{ IKWERRE } & G & $12.50 \pm 0.00^{\mathrm{a}}$ & $0.65 \pm 0.06^{\mathrm{a}}$ & $24.70 \pm 0.12^{\mathrm{a}}$ & $0.06 \pm 0.01^{\mathrm{a}}$ \\
\hline & $\mathbf{H}$ & $23.91 \pm 0.12^{\mathrm{a}}$ & $2.84 \pm 0.01^{\mathrm{a}}$ & $45.24 \pm 0.02^{\mathrm{a}}$ & $1.53 \pm 0.23^{\mathrm{a}}$ \\
\hline & I & $13.41 \pm 0.01^{\mathrm{a}}$ & $1.74 \pm 0.02^{\mathrm{a}}$ & $24.19 \pm 0.04^{\mathrm{a}}$ & $0.07 \pm 0.05^{\mathrm{a}}$ \\
\hline \multicolumn{2}{|c|}{ Ketu Ghana [28] } & 22.89 & - & 744.02 & - \\
\hline \multicolumn{2}{|c|}{ Lagos Nigeria [22] } & 23.33 & 0.09 & 8.35 & - \\
\hline
\end{tabular}

Values are Mean \pm SEM Means in the same column with same superscript alphabet are significantly different at $\mathrm{p} \leq 0.05$.A, B, C= Sampled public primary schools in Obio/Akpor, D, E, F, =sampled public primary schools in Eleme, G, H, I = sampled public primary schools in Ikwerre. 
Activities of localized industries within sampled sites might be responsible for the high Chromium values reported in this study as the result showed that $\mathrm{Cr}$ is of the highest amount of all heavy metals assayed. Chromium on the average as seen in this study were above the average concentration in the earth's crust $0.2 \mu \mathrm{g} / \mathrm{g}$ [42], suggesting an athropogenic $\mathrm{Cr}$ source, Most especially at $\mathrm{E}$ and $\mathrm{H}$ located within Eleme and Ikwerre LGA. The Cr levels could be attributable to the high Industrial activities and vehicular emissions respectively at these locations. However Chromium levels obtained were below that reported by Addo et al. from his work at Ketu-South District Ghana but higher than that reported by Popoola et al. on assessment of heavy metals within selected Schools in Lagos Nigeria [22,28].

This study showed that Arsenic (As) mean levels ranged from $0.058 \pm 0.01$ to $1.53 \pm 0.23 \mathrm{mgKg}^{-1}$ with highest As level seen within $\mathrm{H}$ and minimum level at $\mathrm{F}$.

The International Agency for Research on Cancer (IARC) has classified arsenic and arsenic compounds as carcinogenic to humans [43] other adverse health effects that may be associated with long-term ingestion of inorganic arsenic include developmental effects, neurotoxicity, diabetes, pulmonary disease and cardiovascular disease [43]. Arsenic-induced myocardial infarction, in particular, can be a significant cause of excessive mortality. However, aside Arsenic seen in dust from anthropogenic sources inorganic forms of arsenic have been seen in some types of seaweed. Recent studies suggest hijiki seaweed has very high levels of inorganic arsenic [44]. ATSDR, revealed that in the entire U.S. population, the major source of arsenic exposure is via ingestion of food containing arsenic [45], it was however noted that intake from air, soil, and drinking water is usually much less.

\subsection{Chronic Daily Intake (CDI) or Average Daily Intake Dose}

Different contact routes for heavy metal exposure to individuals were studied in view of the pupils's daily routine. Using the available results obtained from this study and with reference to standard values as set by USEPA. [18], the ADD/CDI was calculated.

The results for the Chronic daily intake (also known as the Average daily intake dose) for the three exposure pathways (namely: ingestion, Dermal and Inhalation) is as shown in Table 5 to Table 7 . The result shows that the major exposure pathway is through oral ingestion followed by dermal contact and lastly inhalation, this is in conformity with the work earlier reported by Mayo et al., and Olujimi et al. [12,14] who revealed that the major exposure pathway of heavy metals in indoor dust to children is through ingestion, followed by dermal contact and then inhalation.

Table 5. AVERAGE DAILY INTAKE DOSE (ADD ingest $)$

\begin{tabular}{|c|c|c|c|c|c|c|c|c|c|}
\hline \multirow{2}{*}{ L.G.A } & \multirow[t]{2}{*}{ SAMPLE } & \multicolumn{2}{|c|}{ Pb (mg/kg) } & \multicolumn{2}{|c|}{ Cd(mg/kg) } & \multicolumn{2}{|c|}{ Cr(mg/kg) } & \multicolumn{2}{|c|}{ As(mg/kg) } \\
\hline & & Adult & Child & Adult & Child & Adult & Child & Adult & Child \\
\hline \multirow{3}{*}{ Obio/Akpor } & A & 2.09E-05 & 1.95E-04 & $1.93 \mathrm{E}-06$ & $1.80 \mathrm{E}-05$ & 3.45E-06 & 5.37E-04 & 7.14E-07 & 6.67E-06 \\
\hline & B & $3.04 \mathrm{E}-05$ & 2.84E-04 & $2.24 \mathrm{E}-06$ & 2.09E-05 & $3.14 \mathrm{E}-06$ & 4.88E-04 & $1.66 \mathrm{E}-06$ & $1.55 \mathrm{E}-05$ \\
\hline & C & 2.59E-05 & 2.42E-04 & 1.83E-06 & $1.71 \mathrm{E}-05$ & 2.63E-06 & $4.10 \mathrm{E}-04$ & $1.46 \mathrm{E}-06$ & $1.36 \mathrm{E}-05$ \\
\hline \multirow{3}{*}{ Eleme } & D & $2.20 \mathrm{E}-05$ & $2.06 \mathrm{E}-04$ & 7.57E-07 & 7.07E-06 & $2.26 \mathrm{E}-06$ & 3.52E-04 & 1.43E-07 & 1.33E-06 \\
\hline & $\mathbf{E}$ & 3.63E-05 & 3.39E-04 & 5.03E-06 & 4.69E-05 & $3.28 \mathrm{E}-06$ & 5.09E-04 & 1.77E-06 & 1.65E-05 \\
\hline & $\mathbf{F}$ & $1.47 \mathrm{E}-05$ & $1.37 \mathrm{E}-04$ & $2.57 \mathrm{E}-07$ & $2.40 \mathrm{E}-06$ & $1.63 \mathrm{E}-06$ & $2.54 \mathrm{E}-04$ & 8.57E-08 & 8.00E-07 \\
\hline \multirow{3}{*}{ Ikwerre } & G & 1.79E-05 & 1.67E-04 & $9.29 \mathrm{E}-07$ & 8.67E-06 & $2.12 \mathrm{E}-06$ & $3.29 \mathrm{E}-04$ & 8.57E-08 & 8.00E-07 \\
\hline & $\mathbf{H}$ & $3.42 \mathrm{E}-05$ & 3.19E-04 & 4.06E-06 & 3.79E-05 & $3.88 \mathrm{E}-06$ & 6.03E-04 & 2.19E-06 & $2.04 \mathrm{E}-05$ \\
\hline & I & $1.92 \mathrm{E}-05$ & $1.79 \mathrm{E}-04$ & $2.49 \mathrm{E}-06$ & 2.32E-05 & 2.07E-06 & 3.23E-04 & $1.00 \mathrm{E}-07$ & $9.33 \mathrm{E}-07$ \\
\hline
\end{tabular}

Table 6. AVERAGE DAILY INTAKE DOSE (ADD Inhalation)

\begin{tabular}{|c|c|c|c|c|c|c|c|c|c|}
\hline \multirow{2}{*}{ L.G.A } & \multirow[t]{2}{*}{ SAMPLE } & \multicolumn{2}{|c|}{ Pb $\left(\mathrm{mgkg}^{-1} \mathrm{day}^{-1}\right)$} & \multicolumn{2}{|c|}{ Cd(mgkg ${ }^{-1}$ day $\left.^{-1}\right)$} & \multicolumn{2}{|c|}{ Cr(mgkg ${ }^{-1}$ day $\left.^{-1}\right)$} & \multicolumn{2}{|c|}{ As(mgkg ${ }^{-1}$ day $\left.^{-1}\right)$} \\
\hline & & Adult & Child & Adult & Child & Adult & Child & Adult & Child \\
\hline \multirow{3}{*}{ Obio/Akpor } & A & 3.07E-09 & 7.16E-09 & $2.84 \mathrm{E}-10$ & $6.62 \mathrm{E}-10$ & $2.54 \mathrm{E}-09$ & $1.97 \mathrm{E}-08$ & $1.05 \mathrm{E}-10$ & $2.45 \mathrm{E}-10$ \\
\hline & $\mathbf{B}$ & 4.47E-09 & $1.04 \mathrm{E}-08$ & $3.30 \mathrm{E}-10$ & $7.70 \mathrm{E}-10$ & $2.31 \mathrm{E}-09$ & $1.79 \mathrm{E}-08$ & $2.44 \mathrm{E}-10$ & $5.69 \mathrm{E}-10$ \\
\hline & C & 3.81E-09 & 8.89E-09 & $2.69 \mathrm{E}-10$ & $6.27 \mathrm{E}-10$ & 1.94E-09 & $1.51 \mathrm{E}-08$ & $2.14 \mathrm{E}-10$ & $5.00 \mathrm{E}-10$ \\
\hline \multirow[t]{2}{*}{ Eleme } & $\mathbf{E}$ & 5.33E-09 & $1.24 \mathrm{E}-08$ & 7.39E-10 & 1.73E-09 & $2.41 \mathrm{E}-09$ & 1.87E-08 & $2.61 \mathrm{E}-10$ & $6.08 \mathrm{E}-10$ \\
\hline & $\mathbf{F}$ & $2.16 \mathrm{E}-09$ & 5.03E-09 & $3.78 \mathrm{E}-11$ & 8.82E-11 & $1.20 \mathrm{E}-09$ & 9.33E-09 & $1.26 \mathrm{E}-11$ & 2.94E-11 \\
\hline \multirow[b]{2}{*}{ Ikwerre } & G & 2.63E-09 & 6.13E-09 & $1.37 \mathrm{E}-10$ & $3.19 \mathrm{E}-10$ & $1.56 \mathrm{E}-09$ & $1.21 \mathrm{E}-08$ & $1.26 \mathrm{E}-11$ & $2.94 \mathrm{E}-11$ \\
\hline & $\mathbf{H}$ & $5.02 \mathrm{E}-09$ & $1.17 \mathrm{E}-08$ & 5.97E-10 & 1.39E-09 & $2.85 \mathrm{E}-09$ & $2.22 \mathrm{E}-08$ & $3.21 \mathrm{E}-10$ & $7.50 \mathrm{E}-10$ \\
\hline
\end{tabular}


Table 7. AVERAGE DAILY INTAKE DOSE (ADD dermal $)$

\begin{tabular}{|c|c|c|c|c|c|c|c|c|c|}
\hline \multirow{2}{*}{ L.G.A } & \multirow[t]{2}{*}{ SAMPLE } & \multicolumn{2}{|c|}{ Pb (mgkg ${ }^{-1}$ day $\left.^{-1}\right)$} & \multicolumn{2}{|c|}{ Cd(mgkg ${ }^{-1}$ day $\left.^{-1}\right)$} & \multicolumn{2}{|c|}{ Cr(mgkg ${ }^{-1}$ day $\left.^{-1}\right)$} & \multicolumn{2}{|c|}{ As(mgkg ${ }^{-1}$ day $\left.^{-1}\right)$} \\
\hline & & Adult & Child & Adult & Child & Adult & Child & Adult & Child \\
\hline \multirow{3}{*}{ Obio/Akpor } & A & 5.17E-08 & 3.33E-07 & 4.78E-09 & 3.07E-08 & $1.43 \mathrm{E}-07$ & 9.17E-07 & 1.77E-09 & $1.14 \mathrm{E}-08$ \\
\hline & B & 7.54E-08 & 4.85E-07 & 5.55E-09 & $3.58 E-08$ & $1.29 \mathrm{E}-07$ & 8.34E-07 & 4.10E-09 & 2.64E-08 \\
\hline & C & $6.42 \mathrm{E}-08$ & 4.13E-07 & 4.53E-09 & 2.91E-08 & $1.09 \mathrm{E}-07$ & $7.00 \mathrm{E}-07$ & 3.61E-09 & 2.32E-08 \\
\hline \multirow{3}{*}{ Eleme } & D & $5.46 \mathrm{E}-08$ & $3.51 \mathrm{E}-07$ & $1.88 \mathrm{E}-09$ & $1.21 \mathrm{E}-08$ & $9.34 \mathrm{E}-08$ & $6.01 \mathrm{E}-07$ & $3.54 \mathrm{E}-10$ & 2.28E-09 \\
\hline & $\mathbf{E}$ & 8.98E-08 & $5.78 \mathrm{E}-07$ & $1.25 \mathrm{E}-08$ & 8.02E-08 & $1.35 \mathrm{E}-07$ & 8.70E-07 & 4.39E-09 & 2.82E-08 \\
\hline & $\mathbf{F}$ & 3.63E-08 & $2.34 \mathrm{E}-07$ & 6.37E-10 & 4.10E-09 & 6.73E-08 & 4.33E-07 & $2.12 \mathrm{E}-10$ & 1.37E-09 \\
\hline \multirow{3}{*}{ Ikwerre } & G & $4.42 \mathrm{E}-08$ & $2.85 \mathrm{E}-07$ & 2.30E-09 & $1.48 \mathrm{E}-08$ & 8.74E-08 & $5.63 \mathrm{E}-07$ & $2.12 \mathrm{E}-10$ & 1.37E-09 \\
\hline & $\mathbf{H}$ & $8.46 \mathrm{E}-08$ & $5.45 \mathrm{E}-07$ & $1.00 \mathrm{E}-08$ & $6.47 \mathrm{E}-08$ & $1.60 \mathrm{E}-07$ & $1.03 \mathrm{E}-06$ & 5.41E-09 & $3.48 E-08$ \\
\hline & I & 4.74E-08 & $3.05 \mathrm{E}-07$ & 6.16E-09 & 3.96E-08 & 8.56E-08 & 5.51E-07 & $2.48 \mathrm{E}-10$ & $1.59 \mathrm{E}-09$ \\
\hline
\end{tabular}

$\mathrm{E}=$ exponential.

The Average daily intake Dose ( $\left.\mathrm{ADD}_{\text {ingestion}}\right)$ were below the reference doses (RFD) as recommended by USEPA and other international bodies. $\mathrm{ADD}_{\text {ingestion }}$ has a range from 3.63E-05 to $1.47 \mathrm{E}-05$; $5.03 \mathrm{E}-06$ to $2.57 \mathrm{E}-07$; 3.88E-06 to $1.63 \mathrm{E}-06$; $2.19 \mathrm{E}-06$ to $8.57 \mathrm{E}-08$ in $\mathrm{mg} \mathrm{kg}^{-1}$ day $^{-1}$ for $\mathrm{Pb}, \mathrm{Cd}, \mathrm{Cr}$, and As ingestion respectively in adults whereas

That of children ranged from 3.39E-04 to 1.37E-04, 4.69E-05 to 2.40E-06, 6.03E-04 to 2.54E-04, 2.04E-05 to 8.00E-07, for $\mathrm{Pb}, \mathrm{Cd}, \mathrm{Cr}$ and As, respectively for ingestion of dust from classroom corners. The maximum levels were seen at $\mathrm{E}$, for $\mathrm{Pb}$ and $\mathrm{Cd}, \mathrm{H}$, for $\mathrm{Cr}$ and $\mathrm{As}$ whereas $\mathrm{F}$, has the lowest $\mathrm{ADD}_{\text {ingest }}$ level for all heavy metals.

Average daily intake dose $\left(\mathrm{ADD}_{\text {Inhalation }}\right)$ ranged from 5.33E-09 to 2.16E-09, 7.39E-10 to 3.78E-11, 2.85E-09 to 1.20E-09, 3.21E-10 to $1.26 \mathrm{E}-11$ for $\mathrm{Pb}, \mathrm{Cd}$, Cr and As respectively all in $\mathrm{mg} \mathrm{kg}^{-1} \mathrm{day}^{-1}$ for adult Population and 1.24E-08 to 5.03E-09, 1.73E-09 to $8.82 \mathrm{E}-11,2.22 \mathrm{E}-08$ to 9.33E-09 and 7.50E-10 to 2.94E-11for Pb, Cd, Cr and As respectively for children Population for dusts in classroom corners. These values as observed were below the inhalation reference dose for the various heavy metals.

Average daily intake dose $\left(\mathrm{ADD}_{\text {dermal }}\right)$ ranged from 8.98E-08 to 3.63E-08, 1.25E-08 to 6.37E-10, 1.60E-07 to 6.73E-08, 5.41E-09 to 2.12E-10, for Pb, Cd, Cr, and As all in $\mathrm{mgkg}^{-1} \mathrm{day}^{-1}$ for adult Population and 5.78E-07 to 2.34E-07, 8.02E-08 to 4.10E-09, 1.03E-06 to 4.33E-07, 3.48E-08 to 1.37E-09 for $\mathrm{Pb}, \mathrm{Cd}$, Cr and As for children Population for dusts in classroom corners. These values as seen are below the dermal reference dose for the various heavy metals as recommended by USEPA [18].

Average daily dose of ingestion of dust particles for all metals were much higher than those of inhalation of resuspended dust particles and dermal absorption of dust particles. The highest levels of risks were associated with the route of ingestion of dust particles to children and adults for all metals, followed by dermal contact and inhalation this corroborates with earlier work on the study of exposure to heavy metals in street dust in zinc smelting district $[46,47]$ and study of exposure to heavy metals in surface dust of Wuhu urban area [48].

\subsection{Non-Carcinogenic Risk Exposure in Public Primary School in Rivers State}

Target Hazard Quotient (THQ) and Hazard index were used to estimate the non-carcinogenic risk due to exposure to heavy metal. Table 8 to Table 11 shows the THQ and $\mathrm{HI}$ values representing non-carcinogenic risks of heavy metals within classroom corners of public primary school dust for children and adult through ingestion, inhalation and dermal contact exposure pathways. The HQ and HI followed same trend as the ADD values in the following order for the respective heavy metals across the sampled schools $\mathrm{E}>\mathrm{H}>\mathrm{B}>\mathrm{C}>\mathrm{D}>\mathrm{A}>\mathrm{I}>\mathrm{G}>\mathrm{F}$ for $\mathrm{Pb}$ in adults and child, $\mathrm{E}>\mathrm{H}>\mathrm{I}>\mathrm{B}>\mathrm{A}>\mathrm{C}>\mathrm{G}>\mathrm{D}>\mathrm{F}$ for $\mathrm{Cd}, \mathrm{H}>\mathrm{A}>\mathrm{E}>\mathrm{B}>\mathrm{C}>\mathrm{D}>\mathrm{G}>\mathrm{I}>\mathrm{F}$ for Cr, $\quad \mathrm{H}>\mathrm{E}>\mathrm{B}>\mathrm{C}>\mathrm{A}>\mathrm{D}>\mathrm{I}>\mathrm{G}>\mathrm{F}$ for As and $\mathrm{H}>\mathrm{E}>\mathrm{B}>\mathrm{C}>\mathrm{A}>\mathrm{I}>\mathrm{D}>\mathrm{G}>\mathrm{F}$ for total $\mathrm{HI}$ for adults and children as seen in classroom corners. The HI values obtained from this study were less than one as set by USEPA, [18] for both adult and children. This however indicates that the region may be relatively free from non- carcinogenic risks due to ingestion, inhalation and dermal contact to classroom dusts. However it was observe in all sampled sites that children population were more prone to these non carcinogenic risks confirming the earlier reports $[5,12,13]$. When compared to the work previously reported by Popoola et al., [22] it was seen that the HI values within public primary schools in Rivers state is within the same range as that in Lagos state, Nigeria. However, similar comparison with indoor dusts in China reported by Cao et al. [49], obtained high HI value for As (21.30), making the location very unhealthy with the citing of a lead-acid battery plant within its environment. Kurt-Karakus, also found non-carcinogenic risk for Cr (HI value of 1.10) in the dust samples collected from offices in Istanbul, Turkey [50]. 
Table 8. TARGET HAZARD QUOTIENT (THQ ingest)

\begin{tabular}{|c|c|c|c|c|c|c|c|c|c|}
\hline \multirow{2}{*}{ L.G.A } & \multirow{2}{*}{ SAMPLE } & \multicolumn{2}{|c|}{$\mathbf{P b}$} & \multicolumn{2}{|c|}{ Cd } & \multicolumn{2}{|c|}{$\mathrm{Cr}$} & \multicolumn{2}{|c|}{ As } \\
\hline & & Adult & Child & Adult & Child & Adult & Child & Adult & Child \\
\hline \multirow{3}{*}{ Obio/Akpor } & A & 0.006 & 0.056 & 0.002 & $1.80 \mathrm{E}-02$ & $1.15 \mathrm{E}-03$ & 1.79E-01 & 2.38E-03 & 2.22E-02 \\
\hline & B & 0.009 & 0.081 & 0.002 & 2.09E-02 & $1.05 \mathrm{E}-03$ & $1.63 \mathrm{E}-01$ & 5.52E-03 & 5.16E-02 \\
\hline & C & 0.007 & 0.069 & 0.002 & $1.71 \mathrm{E}-02$ & 8.78E-04 & $1.37 \mathrm{E}-01$ & $4.86 \mathrm{E}-03$ & 4.53E-02 \\
\hline \multirow{3}{*}{ Eleme } & D & 0.006 & 0.059 & 0.001 & 7.07E-03 & 7.54E-04 & 1.17E-01 & 4.76E-04 & 4.44E-03 \\
\hline & $\mathbf{E}$ & 0.010 & 0.097 & 0.005 & 4.69E-02 & $1.09 \mathrm{E}-03$ & $1.70 \mathrm{E}-01$ & $5.90 \mathrm{E}-03$ & $5.51 \mathrm{E}-02$ \\
\hline & $\mathbf{F}$ & 0.004 & 0.039 & 0.0003 & $2.40 \mathrm{E}-03$ & $5.44 \mathrm{E}-04$ & $8.46 \mathrm{E}-02$ & $2.86 \mathrm{E}-04$ & 2.67E-03 \\
\hline \multirow{3}{*}{ Ikwerre } & $\mathbf{G}$ & 0.005 & 0.048 & 0.001 & 8.67E-03 & $7.06 \mathrm{E}-04$ & $1.10 \mathrm{E}-01$ & $2.86 \mathrm{E}-04$ & 2.67E-03 \\
\hline & $\mathbf{H}$ & 0.010 & 0.091 & 0.004 & 3.79E-02 & $1.29 \mathrm{E}-03$ & $2.01 \mathrm{E}-01$ & 7.29E-03 & $6.80 \mathrm{E}-02$ \\
\hline & I & 0.006 & 0.051 & 0.003 & 2.32E-02 & 6.91E-04 & $1.08 \mathrm{E}-01$ & 3.33E-04 & 3.11E-03 \\
\hline
\end{tabular}

E=exponential

Table 9. TARGET HAZARD QUOTIENT (THQ Inhalation)

\begin{tabular}{|c|c|c|c|c|c|c|c|c|c|}
\hline \multirow{2}{*}{ L.G.A } & \multirow[t]{2}{*}{ SAMPLE } & \multicolumn{3}{|c|}{$\mathbf{P b}$} & \multicolumn{2}{|l|}{ Cd } & $\mathrm{Cr}$ & \multicolumn{2}{|c|}{ As } \\
\hline & & Adult & & Child & Adult & Child & Adult & Adult & Child \\
\hline \multirow{3}{*}{ Obio/Akpor } & $\mathbf{A}$ & 8.77E-07 & 2.05E-06 & $2.84 \mathrm{E}-07$ & $6.62 \mathrm{E}-07$ & $2.54 \mathrm{E}-05$ & $1.97 \mathrm{E}-04$ & $3.50 \mathrm{E}-07$ & 8.17E-07 \\
\hline & B & $1.28 \mathrm{E}-06$ & 2.98E-06 & 3.3E-07 & 7.70E-07 & 2.31E-05 & 1.79E-04 & 8.12E-07 & $1.90 \mathrm{E}-06$ \\
\hline & C & $1.09 \mathrm{E}-06$ & $2.54 \mathrm{E}-06$ & 2.69E-07 & $6.27 \mathrm{E}-07$ & $1.94 \mathrm{E}-05$ & $1.51 \mathrm{E}-04$ & 7.14E-07 & 1.67E-06 \\
\hline \multirow{3}{*}{ Eleme } & D & $9.26 \mathrm{E}-07$ & $2.16 \mathrm{E}-06$ & $1.11 \mathrm{E}-07$ & 2.60E-07 & $1.66 \mathrm{E}-05$ & 1.29E-04 & 7.00E-08 & 1.63E-07 \\
\hline & $\mathbf{E}$ & $1.52 \mathrm{E}-06$ & 3.56E-06 & 7.39E-07 & 1.73E-06 & $2.41 \mathrm{E}-05$ & $1.87 \mathrm{E}-04$ & 8.68E-07 & 2.03E-06 \\
\hline & $\mathbf{F}$ & $6.16 \mathrm{E}-07$ & $1.44 \mathrm{E}-06$ & 3.78E-08 & 8.82E-08 & $1.20 \mathrm{E}-05$ & 9.33E-05 & 4.20E-08 & 9.80E-08 \\
\hline \multirow{3}{*}{ Ikwerre } & $\mathbf{G}$ & 7.5E-07 & $1.75 \mathrm{E}-06$ & $1.37 \mathrm{E}-07$ & 3.19E-07 & $1.56 \mathrm{E}-05$ & $1.21 \mathrm{E}-04$ & $4.20 \mathrm{E}-08$ & $9.80 \mathrm{E}-08$ \\
\hline & $\mathbf{H}$ & $1.44 \mathrm{E}-06$ & 3.35E-06 & 5.97E-07 & 1.39E-06 & 2.85E-05 & $2.22 \mathrm{E}-04$ & $1.07 \mathrm{E}-06$ & $2.50 \mathrm{E}-06$ \\
\hline & I & 8.05E-07 & $1.88 \mathrm{E}-06$ & $3.66 \mathrm{E}-07$ & 8.53E-07 & $1.52 \mathrm{E}-05$ & 1.19E-04 & $4.90 \mathrm{E}-08$ & $1.14 \mathrm{E}-07$ \\
\hline
\end{tabular}

Table 10. TARGET HAZARD QUOTIENT (THQ dermal $_{\text {) }}$

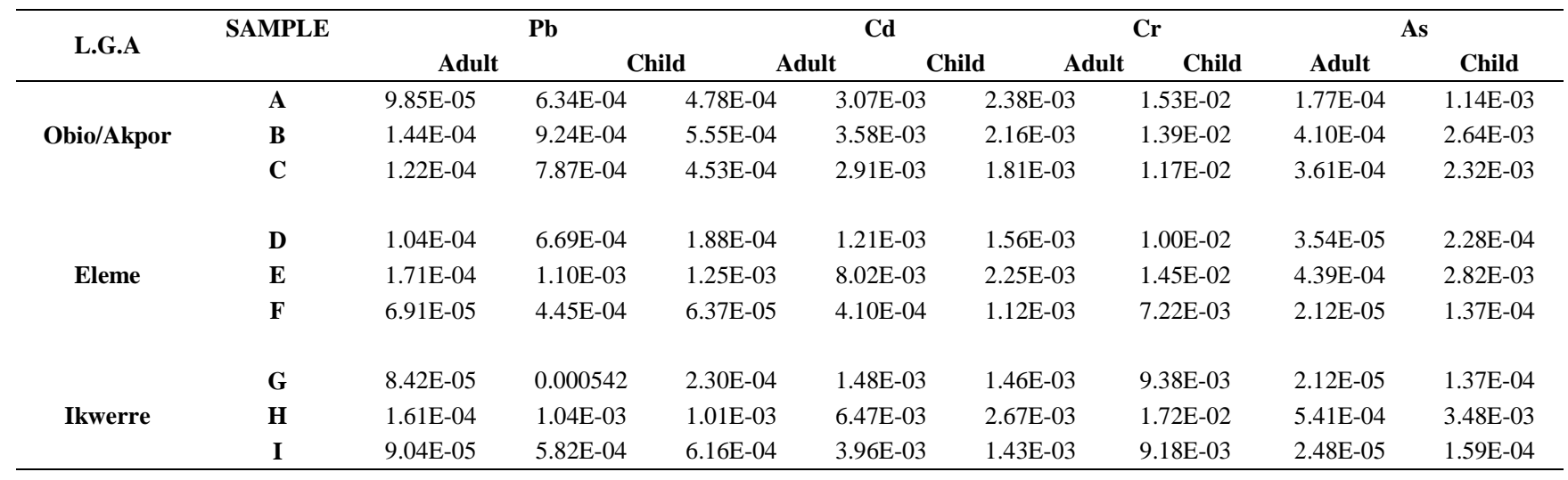

Table 11. HAZARD INDEX (HI)

\begin{tabular}{|c|c|c|c|c|c|c|c|c|c|c|c|}
\hline \multirow{2}{*}{\multicolumn{2}{|c|}{ SAMPLE SITE }} & \multirow{2}{*}{$\begin{array}{c}\text { Pb } \\
\text { Adult }\end{array}$} & \multicolumn{3}{|c|}{ Cd } & \multicolumn{2}{|c|}{$\mathrm{Cr}$} & \multicolumn{2}{|c|}{ As } & \multicolumn{2}{|c|}{$\Sigma$ LHI } \\
\hline & & & Child & Adult & Child & Adult & Child & Adult & Child & Adult & Child \\
\hline \multirow{3}{*}{ Obio/Akpor } & A & $6.06 \mathrm{E}-03$ & 5.63E-02 & $2.41 \mathrm{E}-03$ & $2.11 \mathrm{E}-02$ & $3.56 \mathrm{E}-03$ & $1.94 \mathrm{E}-01$ & $2.56 \mathrm{E}-03$ & $2.33 \mathrm{E}-02$ & $1.46 \mathrm{E}-02$ & $2.95 \mathrm{E}-01$ \\
\hline & B & 8.84E-03 & 8.21E-02 & 2.80E-03 & 2.45E-02 & 3.23E-03 & $1.77 \mathrm{E}-01$ & 5.93E-03 & $5.42 \mathrm{E}-02$ & 2.08E-02 & 3.38E-01 \\
\hline & C & 7.53E-03 & 6.99E-02 & $2.28 \mathrm{E}-03$ & $2.00 \mathrm{E}-02$ & $2.71 \mathrm{E}-03$ & 1.49E-01 & $5.22 \mathrm{E}-03$ & 4.76E-02 & $1.77 \mathrm{E}-02$ & 2.86E-01 \\
\hline \multirow{3}{*}{ Eleme } & D & $6.40 \mathrm{E}-03$ & 5.94E-02 & $9.45 \mathrm{E}-04$ & $8.28 \mathrm{E}-03$ & 2.33E-03 & $1.27 \mathrm{E}-01$ & 5.11E-04 & 4.67E-03 & $1.02 \mathrm{E}-02$ & $1.99 \mathrm{E}-01$ \\
\hline & $\mathbf{E}$ & 1.05E-02 & $9.78 \mathrm{E}-02$ & 6.27E-03 & 5.49E-02 & 3.36E-03 & $1.85 \mathrm{E}-01$ & 6.34E-03 & 5.79E-02 & 2.65E-02 & 3.95E-01 \\
\hline & $\mathbf{F}$ & 4.26E-03 & 3.95E-02 & $3.21 \mathrm{E}-04$ & $2.81 \mathrm{E}-03$ & $1.68 \mathrm{E}-03$ & 9.19E-02 & 3.07E-04 & $2.81 \mathrm{E}-03$ & $6.56 \mathrm{E}-03$ & 1.37E-01 \\
\hline \multirow{3}{*}{ Ikwerre } & G & 5.19E-03 & 4.82E-02 & $1.16 \mathrm{E}-03$ & $1.02 \mathrm{E}-02$ & 2.18E-03 & $1.20 \mathrm{E}-01$ & 3.07E-04 & 2.81E-03 & 8.83E-03 & $1.81 \mathrm{E}-01$ \\
\hline & $\mathbf{H}$ & $9.92 \mathrm{E}-03$ & $9.21 \mathrm{E}-02$ & $5.06 \mathrm{E}-03$ & 4.44E-02 & 3.99E-03 & 2.18E-01 & 7.83E-03 & 7.15E-02 & 2.68E-02 & 4.26E-01 \\
\hline & I & 5.56E-03 & 5.17E-02 & $3.10 \mathrm{E}-03$ & 2.72E-02 & $2.14 \mathrm{E}-03$ & $1.17 \mathrm{E}-01$ & $3.58 \mathrm{E}-04$ & 3.27E-03 & $1.12 \mathrm{E}-02$ & $1.99 \mathrm{E}-01$ \\
\hline
\end{tabular}




\subsection{Carcinogenic Risk Exposure via Dust in Public Primary School in Rivers State}

The results of the carcinogenic risk due to exposure to classroom dusts are shown in Table 12 to Table 15. This is represented by calculating the life cancer risks (LCR) for the three exposure routes. The LCR showed same trend as the $\mathrm{ADD}$ in the order $\mathrm{LCR}_{\text {ingest }}>\mathrm{LCR}_{\text {dermal }}>\mathrm{LCR}_{\text {inhalation }}$. Carcinogenic risks that exceed the Total life cancer risk (TLCR) acceptable values $\left(10^{-4}\right)$ [18] were found in children exposed to $\mathrm{Cr}$ in all the schools except for $\mathrm{F}$ (9.67E-05). However these values were within the range of threshold values $\left(10^{-6}\right.$ to $\left.10^{-4}\right)$ [18] Chromium could be lethal, it has the ability to cause lung cancer, kidney, respiratory tract, reproductive system damage [51]. The TLCR values obtained for $\mathrm{Pb}$ at all School sites and As at D, F, G, H, I, (adult), were below threshold range as set by
USEPA, [18] while the rest of the schools had TLCR values within the range of threshold value. Considering the carcinogenic risk on cumulative effect of the heavy metals assayed, it was observed that children in all the schools are exposed to carcinogenic risks as the $\Sigma$ TLCR was seen to be above the range of threshold values $\left(10^{-6}\right.$ to $\left.10^{-4}\right)$ above which environmental and regulatory agencies consider the risk unacceptable. The adults were seen to have $\Sigma$ TLCR within the range of threshold value. This entails that the adults are less exposed to cancer risk from exposure to classroom dusts containing theses heavy metals ( $\mathrm{Pb}, \mathrm{Cd}, \mathrm{Cr}, \mathrm{As})$. However adequate measures should be taken to prevent increased concentration of these heavy metal as well as prolonged exposure as there could be potential risks with continuous environmental pollution as the $\Sigma$ TLCR tends towards the upper safety limits in adults.

Table 12. LIFE CANCER RISK (LCR ingest $_{\text {) }}$

\begin{tabular}{|c|c|c|c|c|c|c|c|c|c|}
\hline \multirow{2}{*}{\multicolumn{2}{|c|}{ SAMPLE SITE }} & \multicolumn{2}{|c|}{$\mathbf{P b}$} & \multicolumn{2}{|c|}{ Cd } & \multicolumn{2}{|c|}{$\mathrm{Cr}$} & \multicolumn{2}{|c|}{ As } \\
\hline & & Adult & Child & Adult & Child & Adult & Child & Adult & Child \\
\hline \multirow{3}{*}{ Obio/Akpor } & A & $1.77 \mathrm{E}-07$ & 4.14E-07 & $1.22 \mathrm{E}-05$ & $2.84 \mathrm{E}-05$ & 1.73E-06 & 6.71E-05 & $1.07 \mathrm{E}-06$ & $2.50 \mathrm{E}-06$ \\
\hline & B & 2.59E-07 & $6.04 \mathrm{E}-07$ & $1.41 \mathrm{E}-05$ & 3.30E-05 & $1.57 \mathrm{E}-06$ & $6.10 \mathrm{E}-05$ & $2.49 \mathrm{E}-06$ & $5.80 \mathrm{E}-06$ \\
\hline & $\mathrm{C}$ & $2.20 \mathrm{E}-07$ & $5.14 \mathrm{E}-07$ & $1.15 \mathrm{E}-05$ & 2.69E-05 & $1.32 \mathrm{E}-06$ & 5.12E-05 & 2.19E-06 & $5.10 \mathrm{E}-06$ \\
\hline \multirow{3}{*}{ Eleme } & D & $1.87 \mathrm{E}-07$ & 4.37E-07 & 4.77E-06 & $1.11 \mathrm{E}-05$ & 1.13E-06 & 4.40E-05 & $2.14 \mathrm{E}-07$ & $5.00 \mathrm{E}-07$ \\
\hline & $\mathbf{E}$ & $3.08 \mathrm{E}-07$ & 7.19E-07 & 3.17E-05 & 7.39E-05 & $1.64 \mathrm{E}-06$ & 6.37E-05 & 2.66E-06 & $6.20 \mathrm{E}-06$ \\
\hline & $\mathbf{F}$ & $1.25 \mathrm{E}-07$ & 2.91E-07 & $1.62 \mathrm{E}-06$ & 3.78E-06 & 8.16E-07 & 3.17E-05 & $1.29 \mathrm{E}-07$ & $3.00 \mathrm{E}-07$ \\
\hline \multirow{3}{*}{ Ikwerre } & G & $1.52 \mathrm{E}-07$ & $3.54 \mathrm{E}-07$ & 5.85E-06 & 1.37E-05 & $1.06 \mathrm{E}-06$ & 4.12E-05 & $1.29 \mathrm{E}-07$ & $3.00 \mathrm{E}-07$ \\
\hline & $\mathbf{H}$ & 2.90E-07 & 6.77E-07 & $2.56 \mathrm{E}-05$ & 5.96E-05 & $1.94 \mathrm{E}-06$ & 7.54E-05 & 3.28E-06 & 7.65E-06 \\
\hline & I & 1.63E-07 & 3.80E-07 & $1.57 \mathrm{E}-05$ & 3.65E-05 & $1.04 \mathrm{E}-06$ & 4.03E-05 & $1.50 \mathrm{E}-07$ & 3.50E-07 \\
\hline
\end{tabular}

Table 13. LIFE CANCER RISK (LCR inhalation$)$

\begin{tabular}{|c|c|c|c|c|c|c|c|c|c|}
\hline \multirow{2}{*}{\multicolumn{2}{|c|}{ SAMPLE SITE }} & \multicolumn{2}{|c|}{$\mathbf{P b}$} & \multicolumn{2}{|c|}{ Cd } & \multicolumn{2}{|c|}{$\mathrm{Cr}$} & \multicolumn{2}{|c|}{ As } \\
\hline & & Adult & Child & Adult & Child & Adult & Child & Adult & Child \\
\hline \multirow{3}{*}{ Obio/Akpor } & A & $1.29 \mathrm{E}-10$ & 7.52E-11 & $1.79 \mathrm{E}-09$ & $1.04 \mathrm{E}-09$ & 1.04E-09 & 2.02E-09 & $1.58 \mathrm{E}-09$ & $9.19 \mathrm{E}-10$ \\
\hline & B & $1.88 \mathrm{E}-10$ & $1.10 \mathrm{E}-10$ & 2.08E-09 & $1.21 \mathrm{E}-09$ & $9.46 \mathrm{E}-10$ & $1.84 \mathrm{E}-09$ & 3.66E-09 & 2.13E-09 \\
\hline & C & $1.60 \mathrm{E}-10$ & 9.34E-11 & $1.69 \mathrm{E}-09$ & $9.88 \mathrm{E}-10$ & 7.94E-10 & 1.54E-09 & 3.21E-09 & $1.88 \mathrm{E}-09$ \\
\hline \multirow{3}{*}{ Eleme } & D & $1.36 \mathrm{E}-10$ & 7.94E-11 & $7.01 \mathrm{E}-10$ & $4.09 \mathrm{E}-10$ & $6.82 \mathrm{E}-10$ & 1.33E-09 & $3.15 \mathrm{E}-10$ & $1.84 \mathrm{E}-10$ \\
\hline & $\mathbf{E}$ & $2.24 \mathrm{E}-10$ & $1.31 \mathrm{E}-10$ & 4.66E-09 & 2.72E-09 & $9.87 \mathrm{E}-10$ & 1.92E-09 & 3.91E-09 & $2.28 \mathrm{E}-09$ \\
\hline & $\mathbf{F}$ & $9.05 E-11$ & $5.28 \mathrm{E}-11$ & $2.38 \mathrm{E}-10$ & $1.39 \mathrm{E}-10$ & $4.92 \mathrm{E}-10$ & $9.56 \mathrm{E}-10$ & $1.89 \mathrm{E}-10$ & $1.10 \mathrm{E}-10$ \\
\hline \multirow{3}{*}{ Ikwerre } & G & $1.10 \mathrm{E}-10$ & 6.43E-11 & $8.60 \mathrm{E}-10$ & $5.02 \mathrm{E}-10$ & $6.38 \mathrm{E}-10$ & $1.24 \mathrm{E}-09$ & $1.89 \mathrm{E}-10$ & $1.10 \mathrm{E}-10$ \\
\hline & $\mathbf{H}$ & $2.11 \mathrm{E}-10$ & $1.23 \mathrm{E}-10$ & 3.76E-09 & 2.19E-09 & 1.17E-09 & 2.27E-09 & 4.82E-09 & 2.81E-09 \\
\hline & I & $1.18 \mathrm{E}-10$ & $6.90 \mathrm{E}-11$ & 2.30E-09 & $1.34 \mathrm{E}-09$ & $6.25 \mathrm{E}-10$ & $1.22 \mathrm{E}-09$ & $2.21 \mathrm{E}-10$ & $1.29 \mathrm{E}-10$ \\
\hline
\end{tabular}

Table 14. LIFE CANCER RISK (LCR dermal $)$

\begin{tabular}{|c|c|c|c|c|c|c|c|c|c|}
\hline \multirow{2}{*}{\multicolumn{2}{|c|}{ SAMPLE SITE }} & \multicolumn{2}{|c|}{$\mathbf{P b}$} & \multicolumn{2}{|c|}{ Cd } & \multicolumn{2}{|c|}{$\mathrm{Cr}$} & \multicolumn{2}{|c|}{ As } \\
\hline & & Adult & Child & Adult & Child & Adult & Child & Adult & Child \\
\hline \multirow{3}{*}{ Obio/Akpor } & A & - & - & - & - & $1.26 \mathrm{E}-06$ & $1.38 \mathrm{E}-04$ & $7.96 \mathrm{E}-08$ & $1.28 \mathrm{E}-07$ \\
\hline & B & - & - & - & - & 1.15E-06 & $1.25 \mathrm{E}-04$ & $1.85 \mathrm{E}-07$ & 2.97E-07 \\
\hline & C & - & - & - & - & 9.64E-07 & $1.05 \mathrm{E}-04$ & $1.62 \mathrm{E}-07$ & $2.61 \mathrm{E}-07$ \\
\hline \multirow{3}{*}{ Eleme } & D & - & - & - & - & 8.28E-07 & $9.02 \mathrm{E}-05$ & $1.59 \mathrm{E}-08$ & $2.56 \mathrm{E}-08$ \\
\hline & $\mathbf{E}$ & - & - & - & - & $1.20 \mathrm{E}-06$ & $1.31 \mathrm{E}-04$ & $1.97 \mathrm{E}-07$ & $3.18 \mathrm{E}-07$ \\
\hline & $\mathbf{F}$ & - & - & - & - & 5.97E-07 & $6.50 \mathrm{E}-05$ & 9.55E-09 & $1.54 \mathrm{E}-08$ \\
\hline \multirow{3}{*}{ Ikwerre } & G & - & - & - & - & 7.75E-07 & 8.44E-05 & $9.55 \mathrm{E}-09$ & $1.54 \mathrm{E}-08$ \\
\hline & $\mathbf{H}$ & - & - & - & - & $1.42 \mathrm{E}-06$ & $1.55 \mathrm{E}-04$ & $2.44 \mathrm{E}-07$ & 3.92E-07 \\
\hline & I & - & - & - & - & $7.59 \mathrm{E}-07$ & 8.26E-05 & $1.11 \mathrm{E}-08$ & $1.79 \mathrm{E}-08$ \\
\hline
\end{tabular}


Table 15. TOTAL LIFE CANCER RISK (TLCR)

\begin{tabular}{|c|c|c|c|c|c|c|c|c|c|c|c|}
\hline \multirow{2}{*}{\multicolumn{2}{|c|}{ SAMPLE SITE }} & \multicolumn{2}{|c|}{$\mathbf{P b}$} & \multicolumn{2}{|c|}{ Cd } & \multicolumn{2}{|c|}{$\mathrm{Cr}$} & \multicolumn{2}{|c|}{ As } & \multicolumn{2}{|c|}{$\Sigma T L C R$} \\
\hline & & Adult & Child & Adult & Child & Adult & Child & Adult & Child & Adult & Child \\
\hline \multirow{3}{*}{ Obio/Akpor } & A & $1.77 \mathrm{E}-07$ & $4.14 \mathrm{E}-07$ & $1.22 \mathrm{E}-05$ & 2.84E-05 & 2.99E-06 & 2.05E-04 & $1.15 \mathrm{E}-06$ & 2.63E-06 & 1.65E-05 & 2.37E-04 \\
\hline & B & 2.59E-07 & $6.04 \mathrm{E}-07$ & $1.41 \mathrm{E}-05$ & 3.30E-05 & 2.72E-06 & $1.86 \mathrm{E}-04$ & 2.68E-06 & 6.10E-06 & $1.98 \mathrm{E}-05$ & $2.26 \mathrm{E}-04$ \\
\hline & C & 2.20E-07 & $5.14 \mathrm{E}-07$ & 1.15E-05 & 2.69E-05 & $2.28 \mathrm{E}-06$ & $1.56 \mathrm{E}-04$ & 2.36E-06 & 5.36E-06 & $1.64 \mathrm{E}-05$ & 1.89E-04 \\
\hline \multirow{3}{*}{ Eleme } & D & $1.87 \mathrm{E}-07$ & 4.37E-07 & 4.77E-06 & $1.11 \mathrm{E}-05$ & $1.96 \mathrm{E}-06$ & $1.34 \mathrm{E}-04$ & 2.30E-07 & $5.26 \mathrm{E}-07$ & 7.15E-06 & $1.46 \mathrm{E}-04$ \\
\hline & $\mathbf{E}$ & 3.08E-07 & 7.19E-07 & 3.17E-05 & 7.39E-05 & $2.84 \mathrm{E}-06$ & 1.95E-04 & 2.86E-06 & 6.52E-06 & 3.77E-05 & 2.76E-04 \\
\hline & $\mathbf{F}$ & $1.25 \mathrm{E}-07$ & 2.91E-07 & $1.62 \mathrm{E}-06$ & 3.78E-06 & $1.41 \mathrm{E}-06$ & $9.67 \mathrm{E}-05$ & $1.39 \mathrm{E}-07$ & $3.16 \mathrm{E}-07$ & $3.30 \mathrm{E}-06$ & $1.01 \mathrm{E}-04$ \\
\hline \multirow{3}{*}{ Ikwerre } & G & $1.52 \mathrm{E}-07$ & $3.54 \mathrm{E}-07$ & 5.85E-06 & 1.37E-05 & $1.84 \mathrm{E}-06$ & $1.26 \mathrm{E}-04$ & 1.39E-07 & 3.16E-07 & 7.98E-06 & $1.40 \mathrm{E}-04$ \\
\hline & $\mathbf{H}$ & 2.90E-07 & 6.77E-07 & 2.56E-05 & $5.96 \mathrm{E}-05$ & 3.36E-06 & 2.30E-04 & 3.53E-06 & 8.04E-06 & 3.28E-05 & 2.99E-04 \\
\hline & I & $1.63 \mathrm{E}-07$ & $3.80 \mathrm{E}-07$ & $1.57 \mathrm{E}-05$ & 3.65E-05 & $1.80 \mathrm{E}-06$ & $1.23 \mathrm{E}-04$ & $1.61 \mathrm{E}-07$ & 3.68E-07 & $1.78 \mathrm{E}-05$ & $1.60 \mathrm{E}-04$ \\
\hline
\end{tabular}

\section{Conclusion}

It was observed that despite the significant difference of the mean level of the heavy metals obtained across the various L.G.As (Obio/Akpor, Eleme, Ikwerre) at $\mathrm{p} \leq 0.05$, non of the schools show cased non-carcinogenic risk while carcinogenic risks was observed mainly for children due to exposure to heavy metals from classroom dusts as the hazard index obtained for the accessed schools were be1ow the permissible limit, while the Total Life Cancer Risk obtained was within the range of the permissible limit of $1 \times 10^{-6}$ to $1 \times 10^{-4}$ in adults except for children were these values were seen to be above the permissible limit.

\section{Conflicts of Interest}

The authors declare no conflict of interest.

\section{References}

[1] Klepeis, N.E.; Nelson, W.C.; Ott, W.R.; Robinson, J.P.; Tsang, A.M.. The national human activity pattern survey (NHAPS): a resource for assessing exposure to environmental pollutants. J. Exp. Env.Epid. (2001)11: 231-252.

[2] Schweizer, C.; Edwards, R.D.; Bayer-Oglesby, L.; Gauderman, W.J. and Ilacqua; V. Indoor time-microenvironment-activity patterns in seven regions of Europe. J. Exp. Env.Epid. (2007).; 17:170-181.

[3] Tran, D.T.; Alleman, L.Y.; Coddeville, P.; Gallo, J.C. Elemental characterization and source identification of size resolved atmospheric particles in French classrooms. Atmos.Environ. (2012). 54:250-259.

[4] Al-Rajhi, M.A.; Seaward, M.R.D; and Al-Aamar, A.S. (1996). Metal levels in indoor and outdoor dust in Riyadh, Saudi Arabia. Environ. Intl. 22: 315-324.

[5] Tong, T.Y.; Lam, K.C. (2000). Home sweet home? A case study of household dust contamination in Hong Kong. Sci. Total Environ., 256: 115-123.

[6] Al-Khashman, O.A. (2004). Heavy metal distribution in dust, street dust and soils from the work place in Karak Industrial Estate, J.Atmos. Environ.; 28: 6803-6812.

[7] Meza-Figueroa, D.; La O-Villanueva M.D.; Parra, M.L.D. Heavy metal distribution in dust from elementary schools in Hermosillo, Sonora, Mexico. Atmos. Environ. (2007). 41: 276-288.

[8] Hassan, S.K.M. Metal concentrations and distribution in the household, stairs and entryway dust of some Egyptian homes. Atmos.Environ., (2012). 54: 207-215.

http://www.afdevinfo.com/htmlreports/lor/lor_ni_10_15.html retrieved 08/06/2017.
[9] Huang. M.; Wang, W.; Chan, C.Y; Cheung, K.C.; Man, Y.B. Contamination and risk assessment (based on bioaccessibility via ingestion and inhalation) of metal (loid)s in outdoor and indoor particles from urban centers of Guangzhou, China. Science of The Total Environ. (2014). 480: 117-124.

[10] Praveena, S.M.; Abdul, M.N.S.; Aris, A.Z. Determination of heavy metals in indoor dust from primary school (Sri Serdang, Malaysia): estimation of the health risks. J. Environ. Foren.; (2015). 16: 257-263.

[11] Wang, X.; Sato, T.; Xing, B. Health risks of heavy metals to the general public in Tianjin, China via consumption of vegetables and fish. Sci. Total Environ. (2005). 350, 28-37.

[12] Moya J; Bearer CF; Etzel RA. Children's behavior and physiology and how it affects exposure to environmental contaminants. Pediatrics, (2004). 113: 996-1006.

[13] Beamer, P.; Key, M.E.; Ferguson, A.C.; Canales, R.A.; Auyeng, W. Quantified activity pattern data from 6-to-27-month-old farmworker children for use in exposure assessment. Environ. Res. (2008). 108: 239-246.

[14] Olujimi, O.; Steiner, O.; Goessler, W. Pollution indexing and health risk assessments of trace elements in indoor dusts from classrooms, living rooms and offices in Ogun State, Nigeria. $J$. Afri. Earth Sci. (2015). 101: 396-404.

[15] Luo, X.S.; Ding, J.; Xu, B.; Wang, Y.J.; Li, H.B. Incorporating bio accessibility into human health risk assessments of heavy metals in urban park soils. Sci. Total Environ., (2012). 424: 88-96.

[16] United States of Environmental Protection Agency (USEPA). (2002). Supplemental guidance for developing soil screening levels for superfund sites. OSWER 9355/4-24. Washington, DC: Office of Emergency and Remedial Response, and peaceful coexistence Africa World Press, Trenton, New Jersey, pg 72.

[17] United States Department of Energy. The risk assessment information system (USDOE). Oak Ridge, TN: US Department of Energy's Oak Ridge Operations Office (ORO),. 2011 Available at: https://rais.ornl.gov/.

[18] United States of Environmental Protection Agency (USEPA). Integrated. risk information system. Washington, DC: US EPA, 2011. Available at: http://www.epa.gov/IRIS/. Retrieved 02/07/2017.

[19] US Environmental Protection Agency. Framework for Determining a Mutagenic Mode of Action for Carcinogenicity: Review Draft. (2007). Available online: http://www.epa.gov/osa/mmoaframework/pdfs/MMOA-ERDFINAL-83007.pdf (accessed on 3/07/2017).

[20] MEP (Ministry of Environmental Protection of the People's Republic of China). Technical Guidelines for Risk Assessment of Contaminated Sites; China Environmental Science Press: (2014). Beijing, China. (In Chinese).

[21] US Environmental Protection Agency. Risk Assessment Guidance for Superfund Volume 1: Human Health Evaluation Manual (Part A); (1989). Office of Emergency and Remedial Response: Washington, DC, USA.

[22] Popoola, O.E.; Bamgbose, O.; Okonkwo, O.J.; Arowolo, T.A., Popoola, A.O. Heavy metals content in classroom dust of some public primary schools in metropolitan Lagos, Nigeria. Res. J. Environ. Earth Sci. (2012). 4: 460-465.

[23] Aydinalp, C.; Marinova, S. The Effects of Heavy metals on Seed Germination and Plant Growth on Alfalfa plant (Medicago sativa). Bulg.J. Agric.Sci. (2009), 15(4), 347-350. 
[24] Seregin, I.V.; Ivaniov, V.B. Physiological aspects of cadmium and lead toxic effects on higher plants. Russ. J. Plant Phys. (2001). 48: 606-630.

[25] Ademoroti, C. M. A. . Environmental Chemistry and Toxicology, Foludex Press Ltd., Ibadan. (1996). 171-204.

[26] Asia, I. O.; Ekpo, K. E.; Amayo, K. O.; Jegede, D. A. Determination of Lead, Cadmium and Mercury in surrounding water and organs of some species of fish from Ikpoba River in Benin city, Nigeria. Intl. J. Phy. Sci. (2008) 3(11): 289-292.

[27] Uaboi - Egbenni, P. O.; Okolie, P. N.; Martins, O.; Teniola, O. Studies on the occurrence and distribution of heavy metals in sediments in Lagos Lagoon and their effects on benthic microbial population. Afri. J. Environ. Sci. Tech. (2010). 4(6), pp. 343-351, Available online at http://www.academicjournals. org/AJES

[28] Addo, M.A.; Darko, E.O.; Gordon, C.; Nyarko, B.J.B.; Gbadago, J.K. Heavy Metal Concentrations in Road Deposited Dust at KetuSouth District, Ghana. Intl. J. Sci. Tech. (2012). 2(1): 28-29.

[29] Sanborn, M.D.; Abelsohn, A.; Campbell, M.; Weir, E. (2002). Identifying and managing adverse environmental health effects: 3. Lead exposure. Can.Med.Asso. J. 166: 1287-92.

[30] Environmental Protection Agency (EPA). Methods of Chemical Analysis of Water and Waste. Analytical Quality Control Laboratory, cin cinnati, O.H., US. Enviromental Protection Agency, Water Pollution Control Resource. (1971). Series. No. 1805GWV05/71.

[31] Corbett, D. R.; Dillon, K.; Burnett, W.; Schaefer, G. The special variability of nitrogen and phosphorous concentration in sand aquifer influenced by onsite sewage treatment and disposal systems: a case study on St. George Island, Florida. Environ.Pol. (2002). 117: 337-345.

[32] Iqbal, M. A.; Chaudhary, M.N.; Zaib, S.; Imran, M.; Ali, K .; Iqbal, A. Accumulation of Heavy Metals $(\mathrm{Ni}, \mathrm{Cu}, \mathrm{Cd}, \mathrm{Cr}, \mathrm{Pb})$ in Agricultural Soils and Spring Seasonal Plants, Irrigated by Industrial Waste Water. J.Environ. Tech. Mgt. (2011). 2:1. Retrieved June 3, 2017 from http://icoci.org/jetm

[33] Novey, H. S.; Habib, M. "Asthma and IgE antibodies induced by chromium and nickel salts.” Journal of Allergy \& Clinical Immunology. (1983). 72(4): 407-412.

[34] Lindberg, E.; Vesterberg, O. "Urinary excretion of proteins in chromeplaters, exchromeplaters and referents.” Scan. J.W.Environ. Health. (1983). 9(6), 505-510.

[35] Dayan, A. D.; Paine, A.J. "Mechanisms of chromium toxicity, carcinogenicity and allergenicity: review of the literature from 1985 to 2000.” Hum. Expt. Tox.(2001). 20(9): 439-51.

[36] Polak, L. "Immunology of chromium. In: Chromium: metabolism and toxicity.” Burrows, D, ed. Boca Raton, FL: CRC Press,: (1983). 51-135.

[37] Bruynzeel, D. P.;Hennipman, G. "Irritant contact dermatitis and chrome-passivated metal.” Contact Dermatitis (1988). 19(3): 175-179.
[38] Lewis, R. "Occupational Exposures: Metals. In: Current Occupational \& Environmental Medicine. LaDou, J. editor. 3rd Ed.” Lange Medical Books/McGraw-Hill Companies, Inc.. (2004). 439-441.

[39] Agency for Toxic Substances and Disease Registry "Toxicological Profile for Chromium.” (2000). http://www.atsdr.cdc.gov/toxprofiles/tp.asp?id=62\&tid=17. retrieved 08/06/2017

[40] Gibb, H. J.; Lees, P.S. "Lung cancer among workers in chromium chemical production.” Amer. J. Ind. Med. (2000). 38(2): 115-126.

[41] Park, R. M.; Bena, J.F. "Hexavalent chromium and lung cancer in the chromate industry: a quantitative risk assessment.” Risk Analysis (2004). 24(5): 1099-1108.

[42] Katz, S. A.; Salem, H. "The toxicology of chromium with respect to its chemical speciation: a review." J. Appl. Tox. (1993). 13(3): 217-224.

[43] World Health Organization, Arsenic (2016). http://www.who.int/media centre /factsheets /fs372 /en/ retrieved $17 / 06 / 1$

[44] Rose, M.; Lewis, J.; Langford, N.; Baxter, M.; Origgi, S.; Barber, MArsenic in seaweed-forms, concentration and dietary exposure. Food Chemi. Toxicol. (2007). 45(7): 1263-1267.

[45] Agency for Toxic Substances and Disease Registry. [ATSDR] Toxicological profile for arsenic. Draft for Public Comment. Atlanta GA;. Available from: http://www.atsdr.cdc.gov/toxprofiles/tp.asp?id=22\&tid=3. (2007). retrieved 04/07/2017

[46] Zheng, N.; Liu, J.; Wang, Q.; Liang, Z. Health risk assessment of heavy metal exposure to street dust in the zinc smelting district, Northeast of China. Sci. Total Environ. (2010). 408, 726-733.

[47] Junhua, M.; Wichitra, S. Distribution and Health Risk Assessment of Heavy metals in Surface Dusts of Maha Sarakham Municipality. Proce. - Soc.Behav. Sci. (2012). 50, 280-293.

[48] Fang, F.; Jiang, B.; Wang, H.; Xie, H. Particle size distribution and health risk assessment of heavy metals in surface dust of Wuhu urban area. Geo. Res. (2010). 29(7), 1193-1202.

[49] Cao, S.; Duan, X.; Zhao, X.; Wang, B.; Ma, J. Health risk assessment of various metal(loid)s via multiple exposure pathways on children living near a typical lead-acid battery plant, China. Environ.Pol.; (2015). 200:16-23.

[50] Kurt-Karakus, P.B. Determination of heavy metals in indoor dust from Istanbul, Turkey: Estimation of the health risk. Environ.Intl, (2012). 50:47-55

[51] Wilbur, S.; Abadin, H.; Fay, M.; Yu, D.; Tencza, B. Toxicological Profile for Chromium. Atlanta (GA): Agency for Toxic Substances and Disease Registry (US). 3, Health Effects. 2012. Available at:

http://www.ncbi.nlm.nih.gov/books/NBK158851/ retrieved 7/6/17 